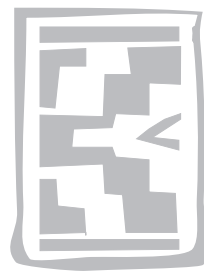

\title{
Persistence mechanisms in tick-borne diseases
}

\author{
A.F. BARBET \\ Department of Infectious Diseases \& Pathology, College of Veterinary Medicine \\ University of Florida, Gainesville, Florida, USA
}

\begin{abstract}
BARBET, A.F. 2009. Persistence mechanisms in tick-borne diseases. Onderstepoort Journal of Veterinary Research, 76:53-58

The use of new, highly sensitive diagnostic methods has revealed persistent infections to be a common feature of different tick-borne diseases, such as babesiosis, anaplasmosis and heartwater. Antigenic variation can contribute to disease persistence through the continual elaboration of new surface structures, and we know in several instances how this is achieved. Known or suspected mechanisms of persistence in babesial parasites include cytoadhesion and rapid variation of the adhesive ligand in Babesia bovis and genetic diversity in several merozoite stage proteins of different Babesia spp. In Anaplasma, extensive variation in the pfam01617 gene family accompanies cycling of organism levels in chronic infection. One result from the pioneering research at Onderstepoort is the definition of a related polymorphic gene family that is likely involved in immunity against heartwater disease. We are beginning to understand the sizes of the antigenic repertoires and full definition is close, with the possibility of applying simultaneous high-throughput sequencing to the order of 1000 small genomes. We also, for the first time, can consider modifying these genomes and looking at effects on persistence and virulence. However, important biological questions remain unanswered; for example, why we are seeing a new emerging Anaplasma infection of humans and is infection of endothelial cells by Anaplasma significant to persistence in vivo.
\end{abstract}

\section{INTRODUCTION}

Despite extensive investigation over the last 100 years, many vector-borne infectious diseases remain resistant to human solutions. Some of the most intransigent of these are infections that induce a 'carrier' state, where the animal remains infected, is still able to transmit organisms to the vector, but may show disease symptoms intermittently or not at all. Indeed, it may be difficult to detect the infection by classical means. Some examples are those infections caused by African trypanosomes, Babesia parasites, Anaplasma or Borrelia bacteria (Allred \& AlKhedery 2004; Horn 2004; Palmer, Futse et al. 2006; Bankhead \& Chaconas 2007). In many cases, it is now evident through the use of sensitive molecular diagnostic methods that a typical infection course consists of numerous relapsing peaks of organisms separated by time periods when they are not detected (Burgdorfer \& Mavros 1970; Kieser, Eriks et al. 1990; Calder, Reddy et al. 1996; Zheng, Sentsui et al. 1997; Granquist, Stuen et al. 2008). This has been known for many years with trypanosome infections but only more recently for some of the other infectious agents. Nevertheless, some molecular characteristics of these infections resemble those of trypanosomes, but with their own particular special features. I consider here our current understanding of some of these molecular characteristics.

\section{DISCUSSION}

Taking African trypanosomes as the original, moststudied paradigm, we know that the Variable Surface Glycoprotein (VSG) that covers the cytoplasmic 
membrane is responsible for the ensuing battle with the host immune system and we have extensive information about its structure, variation and mechanisms of expression (Barry \& McCulloch 2001; Vanhamme, Pays et al. 2001; Borst 2002; McCulloch 2004; Pays, Vanhamme et al. 2004). Despite data showing large differences in VSG structure as the trypanosome undergoes antigenic variation during infection, we know that VSG expression is not totally random and VSG repertoires are not entirely distinct in different places (Hutchinson, Picozzi et al. 2007). In fact, there are examples of shared variants between VSGs in East and West Africa and South America (Vervoort, Barbet et al. 1981; Magnus, Vervoort et al. 1982). Nevertheless, the repertoires are large (with > 1500 genes in each trypanosome encoding VSGs) and largely divergent in different places and at different times (Barry, Crowe et al. 1983; Barry, Marcello et al. 2005; Berriman, Ghedin et al. 2005; Hutchinson, Picozzi et al. 2007). Moreover, the use of different segments of these $>1500$ genes to create novel trypanosome identities through recombination extends the repertoire size enormously (Roth, Bringaud et al. 1989; Kamper \& Barbet 1992; Barbet \& Kamper 1993; Marcello \& Barry 2007) . This concept of antigenic repertoire size is useful in analyzing the epidemiology of many relapsing infectious diseases and the possibilities for control.

So, what do we know about tick-borne diseases important to animal production? Babesia bovis expresses a novel surface antigen, known as the Variant Erythrocyte Surface Antigen (VESA) 1, on the surface of infected erythrocytes (O'Connor, Lane et al. 1997). It is thought to mediate binding of parasitized erythrocytes to endothelial cells, thereby causing parasite sequestration in small capillaries (O'Connor, Long et al. 1999). This helps the parasite to avoid passage through the spleen and consequent removal. Sequestration in the microvasculature is an important feature of babesiosis and is often found in the dangerous cerebral form of the disease. VESA1 is strongly recognized during bovine infection, with variant-specific antibodies detected shortly after the respective parasitemic peaks containing the homologous organisms. In a recent study (Al-Khedery \& Allred 2006), a genomic expression site for VESA1 was described which had acquired at least three different short-coding DNA segments from elsewhere in the genome, suggesting an analogous mechanism to amplify the VESA1 repertoire in Babesia parasites to that in trypanosomes. The VESA1 gene repertoire size in a single Babesia organism was estimated at $>350$ (for one of the two VESA1 subu- nits) (Al-Khedery \& Allred 2006), although genome sequence data put the repertoire size at closer to 150 copies (Brayton, Lau et al. 2007), without considering the effects of repertoire amplification by recombination. Therefore, in both trypanosomes and Babesia, which are protozoans with genome sizes of $35 \mathrm{Mb}$ and $8.2 \mathrm{Mb}$, respectively, there are large, amplifiable repertoires of variant surface antigens.

One might expect the situation to be less complex in Anaplasma because of the smaller genome size of prokaryotes (1.2 Mb for Anaplasma marginale). In fact, this appears to be the case, with two variant outer membrane proteins (OMPs) identified, MSP2 and MSP3 (Barbet, Lundgren et al. 2000; Brayton, Meeus et al. 2003; Meeus, Brayton et al. 2003). Messenger RNA encoding these molecules is transcribed from single genomic expression sites to which approximately seven MSP2 pseudogenes and seven MSP3 pseudogenes contribute sequence by recombination (Brayton, Knowles et al. 2001). As with trypanosomes and Babesia, the variant repertoire is amplifiable in $A$. marginale, because of the use of different pseudogenes and pseudogene segments to create mosaic expression site sequences. Although this extends the repertoire of variant MSP2 and MSP3 enormously, the ultimate size is limited by the relatively small pool of donor pseudogenes. An important unknown question is how much this pool of donor sequences varies with time and location. We do know that many pseudogenes are shared by strains from diverse locations and that epidemic spread of the organism appears associated with the introduction of organisms carrying different MSP2 pseudogenes (Rodriguez, Palmer et al. 2005).

Anaplasma phagocytophilum is a related species to A. marginale which, although known for $>200$ years as a pathogen of ruminants (cases in more than 300000 Norwegian lambs annually) (Stuen 2007), is now causing severe infections in dogs and humans (Dumler, Choi et al. 2005; Lester, Breitschwerdt et al. 2005; Poitout, Shinozaki et al. 2005; Dumler, Barat et al. 2007; Jensen, Simon et al. 2007; Beall, Chandrashekar et al. 2008; Kohn, Galke et al. 2008). Interestingly, the $A$. phagocytophilum genome contains $>100$ genes and pseudogenes homologous to MSP2 of $A$. marginale and likewise a single expression site to which they donate variant sequences (Barbet, Meeus et al. 2003; Wang, Rikihisa et al. 2004; Lin \& Rikihisa 2005; Dunning Hotopp, Lin et al. 2006). As with $A$. marginale, the A. phagocytophilum ortholog (MSP2/P44) is immunoprotective against homologous variants (Palmer, Oberle et al. 
1988; Wang, Kikuchi et al. 2006). Although the potential variant repertoire appears larger than in $A$. marginale, it is known that many similar variants are expressed in the multiple different animal species infected by $A$. phagocytophilum in the USA, possibly indicating a more recent introduction to the continent and less evolutionary diversification of the donor gene repertoire than in European strains (Barbet, Lundgren et al. 2006).

Of great significance to Africa is the tick-borne disease of heartwater and, here too, we now know much more of the potential variant OMP repertoire. This is, in large part, due to the pioneering research of the Onderstepoort Veterinary Institute which developed culture methods to grow Ehrlichia (formerly Cowdria) ruminantium (Bezuidenhout, Paterson et al. 1985) and then to obtain a complete genome sequence (Collins, Liebenberg et al. 2005). We are fortunate in this case to have more than one genome sequence, from both an African and a Caribbean strain (Frutos, Viari et al. 2006) of E. ruminantium. Although the ehrlichias express a related group of variable but immunoprotective (Nyika, Mahan et al. 1998; Nyika, Barbet et al. 2002; Yager, Bitsaktsis et al. 2005) OMPs to the MSP2s of the anaplasmas, they do not appear to have a similar system of antigenic variation that involves extensive recombination into a single genomic expression site. This is not to say that there are no antigenic differences in OMPs between strains and, in fact, breaks in protection against different strains have been a continual problem for development of vaccines against heartwater disease (Jongejan, Thielemans et al. 1991; Jongejan, Vogel et al. 1993; Mahan, Allsopp et al. 1999). The MSP2-related OMPs of E. ruminantium are encoded by a tandem group of 16 genes (Van Heerden, Collins et al. 2004) one of which appears to encode the major OMP expressed in mammals and a second the major OMP in ticks (Postigo, Taoufik et al. 2008). This leaves a question concerning the role of the remaining paralogs. In Ehrlichia chaffeensis, which has a similar genomic structure of MSP2-related paralogs to E. ruminantium, sensitive proteomic methods have detected expression of most paralogs despite the dominant expression of certain paralogs in ticks or mammals (Ge \& Rikihisa 2007; Seo, Cheng et al. 2008). Analysis of RNA transcripts has suggested that the same may be true for E. ruminantium (Bekker, Postigo et al. 2005). It is also clear that both major and minor expressed paralogs are variant in different strains of E. ruminantium throughout Africa and the Caribbean (Reddy, Sulsona et al. 1996; Barbet, Byrom and Mahan, unpublished). Therefore, all paralogs could be involved in expression of the total antigenic identity of E. ruminantium, as they appear to be in Anaplasma.

In A. marginale, an interesting hypothesis has been proposed that the ability of strains to superinfect (and ultimately to cause epidemic spread and influence cross-protection by vaccines) depends on whether or not a superinfecting strain has a different donor pseudogene (for OMP expression) repertoire (Futse, Brayton et al. 2008). If it does, then the superinfecting strain can overcome pre-existing immunity developed over a long time period of infection in carrier animals. This is supported by data from the MSP2 pseudogene repertoire and, currently, the involvement of the other known variant OMP, MSP3, in this process is not clear. There are opportunities to test this theory in other systems. For example, despite the $>100$ genes and pseudogenes potentially contributing to MSP2/P44 variants in A. phagocytophilum, there are two US strains, MRK and HZ, which differ in (presence or absence of) only two pseudogenes (Dunning Hotopp, Lin et al. 2006). One might predict heavy usage of these two pseudogenes in a superinfection of MRK-infected (longterm carrier) animals by $\mathrm{HZ}$. If true for other tickborne diseases, knowledge of the total repertoire of contributing variant genes to OMP diversity becomes of paramount importance to understand disease epidemiology and for vaccine development. Conceivably, this might be achieved for the smaller genome organisms using second and third generation genome-sequencing capable of obtaining, e.g. 1000 genome sequences of diverse $E$. ruminantium strains (Margulies, Egholm et al. 2005; Holt \& Jones 2008).

Complementary to the new power of genome sequencing technology to evaluate variant repertoires in tick-borne diseases is the ability to introduce foreign DNA and investigate phenotypic effects. This has been achieved with $A$. phagocytophilum by transposon mutagenesis (Felsheim, Herron et al. 2006), but directed methods of gene knock-out in $A$. marginale, Babesia or Ehrlichia are still lacking, although standard in trypanosomes and other parasites and bacteria for many years. Potentially, these methods offer the ability to verify definitively the importance of OMP variation in persistent infections, as well as to use other approaches towards vaccines through deliberate attenuation. Despite the extensive work over the last 100 years, we are still discovering new and unforeseen aspects of these organisms, such as the ability to continuously culture A. marginale, thought to infect only erythrocytes, in endothelial cells (Munderloh, Lynch et al. 2004; 
Wamsley \& Barbet 2008). Therefore, although much is now known about these persistent tick-borne infections and there are good prospects for control through the application of new technology, we should recognize that there is much to be discovered about these fascinating organisms. The rigorous and critical application of the scientific method is as necessary now as it was in Theiler's day.

\section{REFERENCES}

AL-KHEDERY, B. \& ALLRED, D.R. 2006. Antigenic variation in Babesia bovis occurs through segmental gene conversion of the ves multigene family, within a bidirectional locus of active transcription. Molecular Microbiology, 59:402-414.

ALLRED, D.R. \& AL KHEDERY, B. 2004. Antigenic variation and cytoadhesion in Babesia bovis and Plasmodium falciparum: different logics achieve the same goal. Molecular and Biochemical Parasitology, 134:27-35.

BANKHEAD, T. \& CHACONAS, G. 2007. The role of VIsE antigenic variation in the Lyme disease spirochete: persistence through a mechanism that differs from other pathogens. Molecular Microbiology, 65:1547-1558.

BARBET, A.F. \& KAMPER, S.M. 1993. The importance of mosiac genes to trypanosome survival. Parasitology Today, 9:6366 .

BARBET, A.F., LUNDGREN, A., YI, J., RURANGIRWA, F.R. \& PALMER, G.H. 2000. Antigenic variation of Anaplasma marginale by expression of MSP2 mosaics. Infection and Immunity, 68:6133-6138.

BARBET, A.F., MEEUS, P.F., BELANGER, M., BOWIE, M.V., YI, J., LUNDGREN, A.M., ALLEMAN, A.R., WONG, S.J., CHU, F.K., MUNDERLOH, U.G. \& JAURON, S.D. 2003. Expression of multiple outer membrane protein sequence variants from a single genomic locus of Anaplasma phagocytophilum. Infection and Immunity, 71:1706-1718.

BARBET, A.F., LUNDGREN, A.M., ALLEMAN, A.R., STUEN, S., BJOERSDORFF, A., BROWN, R.N., DRAZENOVICH, N.L. \& FOLEY, J.E. 2006. Structure of the expression site reveals global diversity in MSP2 (P44) variants in Anaplasma phagocytophilum. Infection and Immunity, 74:6429-6437.

BARRY, J.D., CROWE, J.S. \& VICKERMAN, K. 1983. Instability of the Trypanosoma brucei rhodesiense metacyclic variable antigen repertoire. Nature, 306:699-701.

BARRY, J.D. \& MCCULLOCH, R. 2001. Antigenic variation in trypanosomes: enhanced phenotypic variation in a eukaryotic parasite. Advances in Parasitology, 49:1-70.

BARRY, J.D., MARCELLO, L., MORRISON, L.J., READ, A.F., LYTHGOE, K., JONES, N., CARRINGTON, M., BLANDIN, G., BOHME, U., CALER, E., HERTZ-FOWLER, C., RENAULD, H., EL-SAYED, N. \& BERRIMAN, M. 2005. What the genome sequence is revealing about trypanosome antigenic variation. Biochemical Society Transactions, 33:986-989.

BEALL, M.J., CHANDRASHEKAR, R., EBERTS, M.D., CYR, K.E., DINIZ, P.P., MAINVILLE, C., HEGARTY, B.C., CRAWFORD, J.M. \& BREITSCHWERDT, E.B. 2008. Serological and molecular prevalence of Borrelia burgdorferi, Anaplasma phagocytophilum, and Ehrlichia species in dogs from Minnesota. Vector-borne Zoonotic Diseases, 8:455-464.

BEKKER, C.P., POSTIGO, M., TAOUFIK, A., BELL-SAKYI, L., FERRAZ, C., MARTINEZ, D. \& JONGEJAN, F. 2005. Transcription analysis of the major antigenic protein 1 multigene family of three in vitro-cultured Ehrlichia ruminantium isolates. Journal of Bacteriology, 187:4782-4791.

BERRIMAN, M., GHEDIN, E., HERTZ-FOWLER, C., BLANDIN, G., RENAULD, H., BARTHOLOMEU, D.C., LENNARD, N.J., CALER, E., HAMLIN, N.E., HAAS, B., BOHME, U., HANNICK, L., ASLETT, M.A., SHALLOM, J., MARCELLO, L., HOU, L., WICKSTEAD, B., ALSMARK, U.C., ARROWSMITH, C., ATKIN, R.J., BARRON, A.J., BRINGAUD, F., BROOKS, K., CARRINGTON, M., CHEREVACH, I., CHILLINGWORTH, T.J., CHURCHER, C., CLARK, L.N., CORTON, C.H., CRONIN, A., DAVIES, R.M., DOGGETT, J., DJIKENG, A., FELDBLYUM, T., FIELD, M.C., FRASER, A., GOODHEAD, I., HANCE, Z., HARPER, D., HARRIS, B.R., HAUSER, H., HOSTETLER, J., IVENS, A., JAGELS, K., JOHNSON, D., JOHNSON, J., JONES, K., KERHORNOU, A.X., KOO, H., LARKE, N., LANDFEAR, S., LARKIN, C., LEECH, V., LINE, A., LORD, A., MACLEOD, A., MOONEY, P.J., MOULE, S., MARTIN, D.M., MORGAN, G.W., MUNGALL, K., NORBERTCZAK, H., ORMOND, D., PAI, G., PEACOCK, C.S., PETERSON, J., QUAIL, M.A., RABBINOWITSCH, E., RAJANDREAM, M.A., REITTER, C., SALZBERG, S.L., SANDERS, M., SCHOBEL, S., SHARP, S., SIMMONDS, M., SIMPSON, A.J., TALLON, L., TURNER, C.M., TAIT, A., TIVEY, A.R., VAN AKEN, S., WALKER, D., WANLESS, D., WANG, S., WHITE, B., WHITE, O., WHITEHEAD, S., WOODWARD, J., WORTMAN, J., ADAMS, M.D., EMBLEY, T.M., GULL, K., ULLU, E., BARRY, J.D., FAIRLAMB, A.H., OPPERDOES, F., BARRELL, B.G., DONELSON, J.E., HALL, N., FRASER, C.M., MELVILLE, S.E. \& EL SAYED, N.M. 2005. The genome of the African trypanosome Trypanosoma brucei. Science, 309:416-422.

BEZUIDENHOUT, J.D., PATERSON, C.L. \& BARNARD, B.J. 1985. In vitro cultivation of Cowdria ruminantium. Onderstepoort Journal of Veterinary Research, 52:113-120.

BORST, P. 2002. Antigenic variation and allelic exclusion. Cell, 109:5-8.

BRAYTON, K.A., KNOWLES, D.P., MCGUIRE, T.C. \& PALMER, G.H. 2001. Efficient use of a small genome to generate antigenic diversity in tick-borne ehrlichial pathogens. Proceedings of the National Academy of Science USA, 98:4130-4135.

BRAYTON, K.A., MEEUS, P.F., BARBET, A.F. \& PALMER, G.H. 2003. Simultaneous variation of the immunodominant outer membrane proteins, MSP2 and MSP3, during Anaplasma marginale persistence in vivo. Infection and Immunity, 71: 6627-6632.

BRAYTON, K.A., LAU, A.O.T., HERNDON, D.R., HANNICK, L., KAPPMEYER, L.S., BERENS, S.J., BIDWELL, S.L., BROWN, W.C., CRABTREE, J., FADROSH, D., FELDBLUM, T., FORBERGER, H.A., HAAS, B.J., HOWELL, J.M., KHOURI, H., KOO, H., MANN, D.J., NORIMINE, J., PAULSEN, I.T., RADUNE, D., REN, Q., SMITH, R.K. (Jr), SUAREZ, C.E., WHITE, O., WORTMAN, J.R., KNOWLES, D.P. (Jr), MCELWAIN, T.F. \& NENE, V.M. 2007. Genome sequence of Babesia bovis and comparative analysis of apicomplexan hemoprotozoa. PLoS Pathogens, 3:e148.

BURGDORFER, W. \& MAVROS, A.J. 1970. Susceptibility of various species of rodents to the Relapsing Fever spirochete, Borrelia hermsii. Infection and Immunity, 2:256-259.

CALDER, J.A., REDDY, G.R., CHIEVES, L., COURTNEY, C.H., LITTELL, R., LIVENGOOD, J.R., NORVAL, R.A., SMITH, C. \& DAME, J.B. 1996. Monitoring Babesia bovis infections in cattle by using PCR-based tests. Journal of Clinical Microbiology, 34:2748-2755.

COLLINS, N.E., LIEBENBERG, J., DE VILLIERS, E.P., BRAYTON, K.A., LOUW, E., PRETORIUS, A., FABER, F.E., VAN HEERDEN, H., JOSEMANS, A., VAN KLEEF, M., STEYN, H.C., VAN STRIJP, M.F., ZWEYGARTH, E., JONGEJAN, F., 
MAILLARD, J.C., BERTHIER, D., BOTHA, M., JOUBERT, F., CORTON, C.H., THOMSON, N.R., ALLSOPP, M.T. \& ALLSOPP, B.A. 2005. The genome of the heartwater agent Ehrlichia ruminantium contains multiple tandem repeats of actively variable copy number. Proceedings of the National Academy of Science USA,102:838-843.

DUMLER, J.S., CHOI, K., GARCIA-GARCIA, J.C., BARAT, N.S., SCORPIO, D.G., GARYU, J.W., GRAB, D.J. \& BAKKEN, J.S. 2005. Human granulocytic anaplasmosis and Anaplasma phagocytophilum. Emerging Infectious Diseases, 11:18281834.

DUMLER, J.S., BARAT, N.C., BARAT, C.E. \& BAKKEN, J.S. 2007. Human granulocytic anaplasmosis and macrophage activation. Clinical Infectious Diseases 45:199-204.

DUNNING HOTOPP, J.C., LIN, M., MADUPU, R., CRABTREE, J., ANGIUOLI, S.V., EISEN, J., SESHADRI, R., REN, Q., WU, M., UTTERBACK, T.R., SMITH, S., LEWIS, M., KHOURI, H., ZHANG, C., NIU, H., LIN, Q., OHASHI, N., ZHI, N., NELSON, W., BRINKAC, L.M., DODSON, R.J., ROSOVITZ, M.J., SUNDARAM, J., DAUGHERTY, S.C., DAVIDSEN, T., DURKIN, A.S., GWINN, M., HAFT, D.H., SELENGUT, J.D., SULLIVAN, S.A., ZAFAR, N., ZHOU, L., BENAHMED, F., FORBERGER, H., HALPIN, R., MULLIGAN, S., ROBINSON, J., WHITE, O., RIKIHISA, Y. \& TETTELIN, H. 2006. Comparative genomics of emerging human ehrlichiosis agents. PLoS.Genetics, 2:e21.

FELSHEIM, R.F., HERRON, M.J., NELSON, C. M., BURKHARDT, N.Y., BARBET, A.F., KURTTI, T.J. \& MUNDERLOH, U.G. 2006. Transformation of Anaplasma phagocytophilum. BMC. Biotechnology, 6:42.

FRUTOS, R., VIARI, A., FERRAZ, C., MORGAT, A., EYCHENIE, S., KANDASSAMY, Y., CHANTAL, I., BENSAID, A., COISSAC, E., VACHIERY, N., DEMAILLE, J. \& MARTINEZ, D. 2006. Comparative genomic analysis of three strains of Ehrlichia ruminantium reveals an active process of genome size plasticity. Journal of Bacteriology, 188:2533-2542.

FUTSE, J.E., BRAYTON, K.A., DARK, M.J., KNOWLES, D.P. (Jr) \& PALMER, G.H. 2008. Superinfection as a driver of genomic diversification in antigenically variant pathogens. Proceedings of the National Academy of Science USA, 105: 2123-2127.

GE, Y. \& RIKIHISA, Y. 2007. Surface-exposed proteins of Ehrlichia chaffeensis. Infection and Immunity, 75:3604-3613.

GRANQUIST, E.G., STUEN, S., LUNDGREN, A.M., BRATEN, M. \& BARBET, A.F. 2008. Outer membrane protein sequence variation in lambs experimentally infected with Anaplasma phagocytophilum. Infection and Immunity, 76:120-126.

HOLT, R.A. \& JONES, S.J. 2008. The new paradigm of flow cell sequencing. Genome Research, 18:839-846.

HORN, D. 2004. The molecular control of antigenic variation in Trypanosoma brucei. Current Molecular Medicine, 4:563576.

HUTCHINSON, O.C., PICOZZI, K., JONES, N.G., MOTT, H., SHARMA, R., WELBURN, S.C. \& CARRINGTON, M. 2007. Variant Surface Glycoprotein gene repertoires in Trypanosoma brucei have diverged to become strain-specific. BMC. Genomics, 8:234.

JENSEN, J., SIMON, D., MURUA, E.H., SOLLER, J.T., BULLERDIEK, J., BEELITZ, P., PFISTER, K. \& NOLTE, I. 2007. Anaplasma phagocytophilum in dogs in Germany. Zoonoses and Public Health, 54:94-101.

JONGEJAN, F., THIELEMANS, M.J., BRIERE, C. \& UILENBERG, G. 1991. Antigenic diversity of Cowdria ruminantium isolates determined by cross-immunity. Research in Veterinary Science, 51:24-28.
JONGEJAN, F., VOGEL, S.W., GUEYE, A. \& UILENBERG, G. 1993. Vaccination against heartwater using in vitro attenuated Cowdria ruminantium organisms. Revue d'Elevage et de Medicine Veterinaire des Pays Tropicaux, 46:223-227.

KAMPER, S.M. \& BARBET, A.F. 1992. Surface epitope variation via mosaic gene formation is potential key to long-term survival of Trypanosoma brucei. Molecular and Biochemical Parasitology, 53:33-44.

KIESER, S.T., ERIKS, I.S. \& PALMER, G.H. 1990. Cyclic rickettsemia during persistent Anaplasma marginale infection of cattle. Infection and Immunity, 58:1117-1119.

KOHN, B., GALKE, D., BEELITZ, P. \& PFISTER, K. 2008. Clinical features of canine granulocytic anaplasmosis in 18 naturally infected dogs. Journal of Veterinary Internal Medicine, 22:1289-1295.

LESTER, S.J., BREITSCHWERDT, E.B., COLLIS, C.D. \& HEGARTY, B.C. 2005. Anaplasma phagocytophilum infection (granulocytic anaplasmosis) in a dog from Vancouver Island. Canadian Veterinary Journal, 46:825-827.

LIN, Q. \& RIKIHISA, Y. 2005. Establishment of cloned Anaplasma phagocytophilum and analysis of p44 gene conversion within an infected horse and infected SCID mice. Infection and Immunity, 73:5106-5114.

MAGNUS, E., VERVOORT, T. \& VAN MEIRVENNE, N. 1982. Serological cross-reactions among trypanosome variable antigen isotypes of the subgenus Trypanozoon. Annales de la Societe belge de Medicine tropicale, 62:25-39.

MAHAN, S.M., ALLSOPP, B., KOCAN, K.M., PALMER, G.H. \& JONGEJAN, F. 1999. Vaccine strategies for Cowdria ruminantium infections and their application to other ehrlichial infections. ParasitologyToday, 15:290-294.

MARCELLO, L. \& BARRY, J.D. 2007. Analysis of the VSG gene silent archive in Trypanosoma brucei reveals that mosaic gene expression is prominent in antigenic variation and is favored by archive substructure. Genome Research, 17: 1344-1352.

MARGULIES, M., EGHOLM, M., ALTMAN, W.E., ATTIYA, S., BADER, J.S., BEMBEN, L.A., BERKA, J., BRAVERMAN, M.S., CHEN, Y.J., CHEN, Z., DEWELL, S.B., DU, L., FIERRO, J.M., GOMES, X.V., GODWIN, B.C., HE, W., HELGESEN, S., HO, C.H., IRZYK, G.P., JANDO, S.C., ALENQUER, M.L., JARVIE, T.P., JIRAGE, K.B., KIM, J.B., KNIGHT, J.R., LANZA, J.R., LEAMON, J.H., LEFKOWITZ, S.M., LEI, M., LI, J., LOHMAN, K.L., LU, H., MAKHIJANI, V.B., MCDADE, K.E., MCKENNA, M.P., MYERS, E.W., NICKERSON, E., NOBILE, J.R., PLANT, R., PUC, B.P., RONAN, M.T., ROTH, G.T., SARKIS, G.J., SIMONS, J.F., SIMPSON, J.W., SRINIVASAN, M., TARTARO, K.R., TOMASZ, A., VOGT, K.A., VOLKMER, G.A., WANG, S.H., WANG, Y., WEINER, M.P., YU, P., BEGLEY, R.F. \& ROTHBERG, J.M. 2005. Genome sequencing in microfabricated high-density picolitre reactors. Nature, 437:376-380.

MCCULLOCH, R. 2004. Antigenic variation in African trypanosomes: monitoring progress. Trends in Parasitology, 20:117121.

MEEUS, P.F., BRAYTON, K.A., PALMER, G.H. \& BARBET, A.F. 2003. Conservation of a gene conversion mechanism in two distantly related paralogues of Anaplasma marginale. Molecular Microbiology, 47:633-643.

MUNDERLOH, U.G., LYNCH, M.J., HERRON, M.J., PALMER, A.T., KURTTI, T.J., NELSON, R.D. \& GOODMAN, J.L. 2004. Infection of endothelial cells with Anaplasma marginale and A. phagocytophilum. Veterinary Microbiology, 101:53-64.

NYIKA, A., MAHAN, S.M., BURRIDGE, M.J., McGUIRE, T.C., RURANGIRWA, F. \& BARBET, A.F. 1998. A DNA vaccine 
protects mice against the rickettsial agent Cowdria ruminantium. Parasite Immunology, 20:111-119.

NYIKA, A., BARBET, A.F., BURRIDGE, M.J. \& MAHAN, S.M. 2002. DNA vaccination with map1 gene followed by protein boost augments protection against challenge with Cowdria ruminantium, the agent of heartwater. Vaccine, 20:12151225.

O'CONNOR, R.M., LANE, T.J., STROUP, S.E. \& ALLRED, D.R. 1997. Characterization of a variant erythrocyte surface antigen (VESA1) expressed by Babesia bovis during antigenic variation. Molecular and Biochemical Parasitology, 89:259270.

O'CONNOR, R.M., LONG, J.A. \& ALLRED, D.R. 1999. Cytoadherence of Babesia bovis-infected erythrocytes to bovine brain capillary endothelial cells provides an in vitro model for sequestration. Infection and Immunity, 67:3921-3928.

PALMER, G.H., OBERLE, S.M., BARBET, A.F., GOFF, W.L., DAVIS, W.C. \& MCGUIRE, T.C. 1988. Immunization of cattle with a 36-kilodalton surface protein induces protection against homologous and heterologous Anaplasma marginale challenge. Infection and Immunity, 56:1526-1531.

PALMER, G.H., FUTSE, J.E., KNOWLES, D.P. (Jr) \& BRAYTON, K.A. 2006. Insights into mechanisms of bacterial antigenic variation derived from the complete genome sequence of Anaplasma marginale. Annals of the New York Academy of Science 1078:15-25.

PAYS, E., VANHAMME, L. \& PEREZ-MORGA, D. 2004. Antigenic variation in Trypanosoma brucei: facts, challenges and mysteries. Current Opinions in Microbiology, 7:369-374.

POITOUT, F.M., SHINOZAKI, J.K., STOCKWELL, P.J., HOLLAND, C.J. \& SHUKLA, S.K. 2005. Genetic variants of Anaplasma phagocytophilum infecting dogs in Western Washington State. Journal of Clinical Microbiology, 43:796-801.

POSTIGO, M., TAOUFIK, A., BELL-SAKYI, L., BEKKER, C.P., DE, V.E., MORRISON, W.I. \& JONGEJAN, F. 2008. Host cell-specific protein expression in vitro in Ehrlichia ruminantium. Veterinary Microbiology, 128:136-147.

REDDY, G.R., SULSONA, C.R., HARRISON, R.H., MAHAN, S.M., BURRIDGE, M.J. \& BARBET, A.F. 1996. Sequence heterogeneity of the major antigenic protein 1 genes from Cowdria ruminantium isolates from different geographical areas. Clinical and Diagnostic Laboratory: Immunology, 3:417422.

RODRIGUEZ, J.L., PALMER, G.H., KNOWLES, D.P. (Jr) \& BRAYTON, K.A. 2005. Distinctly different msp2 pseudogene repertoires in Anaplasma marginale strains that are capable of superinfection. Gene, 361:127-132.
ROTH, C., BRINGAUD, F., LAYDEN, R., BALTZ, T. \& EISEN, H. 1989. Active late-appearing variable surface antigen genes in Trypanosoma equiperdum are constructed entirely from pseudogenes. Proceedings of the National Academy of Sciences USA, 86:9375-9379.

SEO, G.M., CHENG, C., TOMICH, J. \& GANTA, R.R. 2008. Total, membrane, and immunogenic proteomes of macrophage and tick cell-derived Ehrlichia chaffeensis evaluated by LCMS/MS and MALDI-TOF methods. Infection and Immunity, $76: 4823-4832$

STUEN, S. 2007. Anaplasma phagocytophilum - the most widespread tick-borne infection in animals in Europe. Veterinary Research Communications, 31, Suppl. 1:79-84.

VAN HEERDEN, H., COLLINS, N.E., BRAYTON, K.A., RADEMEYER, C. \& ALLSOPP, B.A. 2004. Characterization of a major outer membrane protein multigene family in Ehrlichia ruminantium. Gene, 330:159-168.

VANHAMME, L., PAYS, E., MCCULLOCH, R. \& BARRY, J.D. 2001. An update on antigenic variation in African trypanosomes. Trends in Parasitology, 17:338-343.

VERVOORT, T., BARBET, A.F., MUSOKE, A.J., MAGNUS, E., MPIMBAZA, G. \& VAN MEIRVENNE, N. 1981. Isotypic surface glycoproteins of trypanosomes. Immunology 44:223232.

WAMSLEY, H.L. \& BARBET, A.F. 2008. In situ detection of Anaplasma spp. by DNA target-primed rolling-circle amplification of a padlock probe and intracellular colocalization with immunofluorescently labeled host cell von Willebrand factor. Journal of Clinical Microbiology, 46:2314-2319.

WANG, X., RIKIHISA, Y., LAI, T.H., KUMAGAI, Y., ZHI, N. \& REED, S.M. 2004. Rapid sequential changeover of expressed p44 genes during the acute phase of Anaplasma phagocytophilum infection in horses. Infection and Immunity, 72: 6852-6859.

WANG, X., KIKUCHI, T. \& RIKIHISA, Y. 2006. Two monoclonal antibodies with defined epitopes of P44 major surface proteins neutralize Anaplasma phagocytophilum by distinct mechanisms. Infection and Immunity, 74:1873-1882.

YAGER, E., BITSAKTSIS, C., NANDI, B., MCBRIDE, J.W. \& WINSLOW, G. 2005. Essential role for humoral immunity during Ehrlichia infection in immunocompetent mice. Infection and Immunity, 73:8009-8016.

ZHENG, Y.H., SENTSUI, H., NAKAYA, T., KONO, Y. \& IKUTA, K. 1997. In vivo dynamics of equine infectious anemia viruses emerging during febrile episodes: insertions/duplications at the principal neutralizing domain. Journal of Virology, 71: $5031-5039$. 